\title{
Assessing the efficacy of the Tiger Stamp: a policy tool approach
}

\author{
Sheridan Kate Murray ${ }^{1} \cdot$ Peter Kimball Brewitt $^{2}$ (D) \\ Accepted: 30 December 2020 / Published online: 15 January 2021 \\ (C) The Author(s) 2021
}

\begin{abstract}
International conservation presents a unique challenge for American conservation agencies, demanding unique policy tools. To encourage American citizens to support overseas conservation, the Fish and Wildlife Service, the United States Postal Service, and environmental non-governmental organizations collaborated to create the Save Vanishing Species Stamp, a semipostal stamp featuring a tiger. In doing this, these actors relied on the flagship species approach, wherein a charismatic species attracts attention and support for ecological protection. The "Tiger Stamp" has been on sale since 2011, but its effectiveness as a policy tool is uncertain. In this paper, we discuss the Tiger Stamp and analyze its effectiveness from several angles. The stamp's impact on species conservation is uncertain and its sales have been lower than those of past semipostal stamps, but this should be understood in the context of nationwide decline in traditional postal activities and the hortatory effect of the stamp beyond its economic effects. We conclude that the stamp is, on balance, a valuable policy tool, and should be continued.
\end{abstract}

Keywords Charismatic megafauna $\cdot$ Flagship species $\cdot$ Policy tools $\cdot$ Stamp $\cdot$ Tiger

\section{Introduction}

Many wild animal species are in danger of extinction (International Union for Conservation of Nature and Natural Resources 2020). Species decline has gained enormous public salience in the USA (Bruskotter et al. 2018; Kolbert 2014; Tulchin Research 2015). This concern extends to overseas species, as well as those native to the United States. International species are protected under US law by the Endangered Species Act as well as by five Multinational Species Conservation Acts, which focus upon elephants, great apes, rhinoceroses, tigers, and sea turtles. These acts, primarily administered by the US Fish and Wildlife Service (FWS), are funded by Congressional appropriations to Multinational Species Conservation Funds (MSCFs) and donations from private organizations.

International endangered species present an immense policy challenge for American stakeholders. Because their

Peter Kimball Brewitt brewittpk@wofford.edu

1 The Newberry Museum, Newberry, SC, USA

2 Environmental Studies Department, Wofford College, Spartanburg, SC, USA habitats are beyond US jurisdiction, the government cannot compel conservation using punitive incentives, and American citizens cannot elect conservation-minded local lawmakers. Public concern about charismatic species suggests another potential source of support for MSCF'sindividual donations. But monetizing that concern demands creative policy tools (sensu Schneider and Ingram 1990). Here, we analyze one such tool: the Save Vanishing Species semipostal stamp.

\section{Flagship species}

Some animals are particularly charismatic, making them more likely to gain media, scientific, and conservation attention (Ducarme et al. 2013; Jarić et al. 2020; Lorimer 2007). Large body size, fluffy fur, and anthropomorphic features like forward-facing eyes-what Lorimer (2007) calls aesthetic charisma - increase public relatability (Ducarme et al. 2013; Jepson and Barua 2015; Smith et al. 2012) and make these "charismatic megafauna" into a policy image (Baumgartner and Jones 2010). Public agencies and environmental nongovernmental organizations (ENGOs) use charismatic animals as "flagship species" (Home et al. 2009; Lorimer 2007; Thompson and Rog 2019; Verissimo 2019) to "perpetuate 
particular interpretations of nature" (Barua 2011) and act as boundary objects or bridges (Jepson and Barua 2015; Lorimer 2007) that connect the public to conservation - and inspire financial support (Verissimo et al. 2011; Walpole and Leader-Williams 2002). In ecological terms, flagship species are often considered umbrella species, which large ranges include the habitats of many other species (Roberge and Angelstam 2004). Such species can act as proxies for ecosystem health and express aspects of ecosystems to the public (Ducarme et al. 2013). However, flagship species' value as hortatory or social marketing tools is inconsistent (Lundberg et al. 2019; Verissimo et al. 2011). In some cases, they can distort or counteract conservation (Douglas and Winkel 2014; Smith et al. 2020; Verissimo 2019; Verissimo et al. 2011).

The World Wildlife Fund (WWF), a prominent ENGO, further delineates flagship and umbrella species into priority species, whose conservation would mitigate larger threats to their landscapes (WWF 2020a). WWF consciously uses flagship species to "bring substantial financial support to the conservation movement on a worldwide scale" (WWF 2017a, 2020b). Its "Save the "Wow" campaigns emphasized these species' charisma (WWF 2017a, 2019a).

Flagship species are a hortatory/symbolic policy tool, intended to change human behavior by inspiring action (Schneider and Ingram 1990). ENGOs, which cannot compel anyone to do anything, must rely largely on hortatory tools, but less-coercive tools are also useful for public agencies. They can be more publicly palatable than a stricter approach, and can be used in situations where incentive-based policies would be ineffective, such as ocean fishing (Davis and Moretti 2005). Protecting international endangered species is one such situation.

Tigers (Panthera tigris) have been rated the most charismatic animal on earth (Albert et al. 2018). As well as projecting power and menace, tigers are seen as beautiful and even cuddly. Their colorful fur and rounded features make them easy to portray as gentle and friendly. This is particularly true of the Amur tiger (P. tigris altaica), which has thicker fur and a mane. They are also an umbrella species; a male Amur tiger's range can be up to $2000 \mathrm{~km}^{2}$ (Wildlife Conservation Society 2020a). Tigers are the second-most common mascot for American athletic teams (All SportsCaster 2020), and products from gasoline to cereals represent themselves as tigers (Campaign 2012; Kellogs Co. 2005). Both despite and because of their charisma, tiger populations have declined precipitously over the past century, from an estimated 100,000 animals to 3500 (Panthera 2020a; FWS 2020a). This decline has been driven largely by the trade in tiger products, as well as by habitat transformation (FWS 2020a). Big cats are one of WWF's priority species clusters (WWF 2020a). In the USA, tigers were federally listed as endangered in 1970 (FWS 2020b).

\section{The Tiger Stamp}

In 2000, WWF proposed a novel conservation campaign - an American postage stamp (WWF 2014). While ENGOs often sell images of endangered species on clothing or posters, stamps carry the weight and authority of the American government, and reach people who might not actively support conservation groups. To WWF senior vice president Ginette Hemley, the stamp would provide "an easy way for individuals to use their purchasing power to help save vanishing species every time they mail a letter. By purchasing these stamps, anyone can play a direct role in protecting some of our most iconic and endangered wildlife" (WWF 2014). The stamp would feature an Amur tiger cub, allowing stamp buyers and indeed USPS to associate themselves with the charismatic tiger. WWF had partnered with several Asian countries on their own tiger stamps (Kenmore Stamp Company 2020; Thailand Post Company and World Wildlife Fund 2011; WWF 2010). After some years of preparation, in 2010, WWF partnered with FWS and the United States Postal Service (USPS), as well as other conservation groups, to create the Save Vanishing Species Semipostal Stamp, known as the Tiger Stamp. The Multinational Species Conservation Funds Semipostal Stamp Act of 2010 authorized the stamps; they went on sale in 2011 (Fig. 1). The Act enjoyed broad bipartisan support, with 154 cosponsors (80 Democrats, 74 Republicans) in the House representing 48 states and territories (Brown 2010), and passed the Senate with unanimous assent (111th Congress 2010).

Postage stamps have always been symbolic tools. Since their invention in 1840 , nations have represented themselves and honored their priorities through stamps. In the USA, stamps legally represent "positive contributions to American life, history, culture and environment" (USPS Citizens' Stamp Advisory Comittee 2019). Anyone can propose a stamp and have their suggestion screened by the USPS' Citizens' Stamp Advisory Committee (CSAC). The CSAC then recommends new stamps to the Postmaster General. If the stamp is deemed acceptable, USPS commissions artists and designers to submit design ideas, a design is chosen, and the stamp is printed for release (Scott Tiffney, American Philatelic Research Library, personal communication). The effectiveness of stamps as tools to engage the public is demonstrated by the enduring popularity of stamp collecting, which began the year after the stamp's invention (American Philatelic Society 2018).

Governments capitalize on stamps' symbolic power through semipostal stamps, stamps sold for above the firstclass price; the difference goes to a government-approved cause. The first semipostal stamps were released in the British Empire in the 1890s, with the proceeds going to support postal employees, tuberculosis victims, and war veterans (Miller and Terrell 1991). Most countries released semipostals in the following century, but they are relatively new to the 

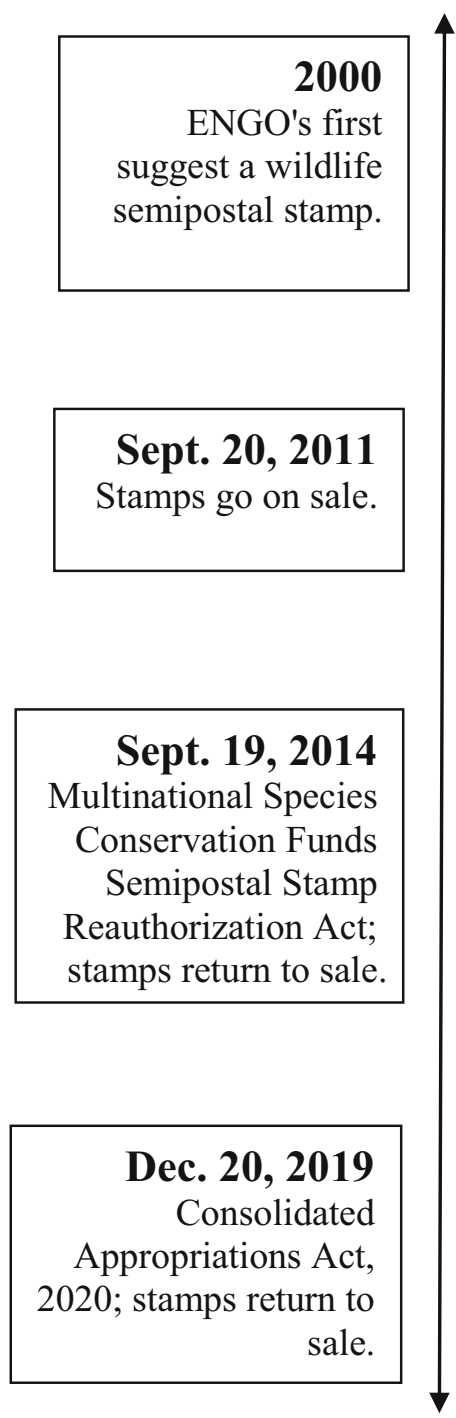

\section{Dec. 31, 2013}

Authorization

lapses; stamps

pulled from sale.

\section{Dec. 31, 2018}

Authorization

lapses; stamps

pulled from sale.

Fig. 1 Tiger Stamp timeline

USA (Miller and Terrell 1991). USPS printed its first semipostal, the congressionally mandated Breast Cancer Research Stamp, in 1998. In 2000, the Semipostal Authorization Act gave USPS discretionary authority to create fundraising stamps to promote causes that are "in the national public interest and appropriate" (106th Congress 2000) but USPS, seeing fundraising as separate from its mission, asked Congress to tell it what to issue (Sheikh et al. 2017).

To create the Save Vanishing Species Stamp, USPS contracted with designer Nancy Stahl. She drew what USPS requested, based on her style and experience producing wildlife stamp images (Stahl, personal communication). In designing the Tiger Stamp, Stahl worked from photographs provided by USPS and had the stamp's green background chosen by USPS art director Derry Noyes, using flat colors to create a cartoon-like "graphic illustration" of the Amur cub (Stahl, personal communication). This design approach allowed USPS to reproduce it clearly at a small size. The stamp

downplays menace in favor of cuddliness. The cub on the stamp has large eyes and a fluffy coat, resembling a stuffed toy tiger (WWF 2020c). Stahl expected that this design would effectively inspire consumers (Stahl, personal communication). USPS did as well, printing 100 million Tiger Stamps; a typical first run is 10-20 million stamps (Tiffney, personal communication).

\section{The life of the Tiger Stamp}

In 2011, the Save Vanishing Species Stamp was announced as a partnership between FWS, USPS, the Multinational Species Fund Coalition, a group of ENGOs including WWF, and the Smithsonian National Zoo, which hosted the initial announcement of the stamp. USPS sold 7.3 million Tiger Stamps in its first quarter on sale (Portman 2014). It has been sold at about a 10 cent premium (USPS Historian 2019). Through mid-2020, 52.7 million Tiger Stamps have been sold, raising \$5.9 million for international endangered species (USPS 2020a) (though availability has fluctuated with congressional authorization). Funds are divided equally among the five MSCF support programs to help protect charismatic international species. Stamp sales have supported 99 field projects in 35 countries, along with $\$ 18,870,331$ in additional leveraged funds contributed by ENGOs (FWS 2019).

The stamp itself became something of a conservation badge for companies and nonprofits. BBDO, an advertising agency, donated its resources to promote the stamp, and Busch Gardens/SeaWorld made it their official stamp (FWS 2011). In 2013, the Detroit Tigers baseball team announced a partnership program wherein the team donated $\$ 26,000$ to FWS' Wildlife Without Borders program, as well as promoting conservation donations and selling the stamp at their stadium (FWS 2015). The Tiger Stamp also appeared on commemorative envelopes celebrating the national champion Clemson University Tigers football team (USPS 2017). This sort of promotion is key in ensuring the success of semipostals (GAO 2005).

Partisan polarization is stark on environmental issues (Dunlap 2019; Hejny 2018), but the stamp has bipartisan support. While this may partly be due to species' charisma, it may also reflect a political calculation. Domestic conservation is likely to conflict with industrial interests and private-property advocates. The Tiger Stamp lets American politicians establish environmental bona fides with less resistance from their constituents. In addition, an attractive feature of the stamp, according to WWF, the Department of the Interior, and Senator Portman, was that it allows consumers to support wildlife conservation "at no cost to the US taxpayer," differing from more expensive conservation efforts (Office of Congressional and Legislative Affairs 2019; Portman 2019b; WWF 2019b). The cost of creating and distributing 
semipostal stamps is similar to that of standard stamps (Government Accountability Office [GAO] 2005).

The Tiger Stamp left circulation as authorization lapsed in 2013 and 2018, but supporters successfully lobbied to revive it (FWS 2020c). ENGOs offered petitions on their websites, encouraging concerned constituents to lobby their representatives (Wildlife Conservation Society 2020b; WWF 2019b), and Interior supported the effort as well (Office of Congressional and Legislative Affairs 2019). In Congress, bills to reauthorize the Tiger Stamp attracted bipartisan sponsorship (Clay 2019; Portman 2019a). Senator Portman emphasized that the existing stock of nearly 50 million Tiger Stamps would be wasted if the stamps went unsold, and cosponsored a reauthorization bill ordering USPS to sell all remaining stamps (Portman 2019b; Portman et al. 2018). Ultimately, reauthorization was folded into the FY 2020 spending bill, returning the stamp to sale but without requiring that it be sold out (116th Congress 2019). The Tiger Stamp's status after 2020 is uncertain.

\section{Evaluation}

As a unique policy tool, semipostal stamps have been the focus of ongoing scrutiny and analysis (Owens 2000; Sheikh et al. 2017; GAO 2003, 2005, 2007). The Tiger Stamp, with its appealing design, charismatic flagship species, and ongoing popular cause, has the qualities to be successful (GAO 2005). But while actors' statements have been positive (Dayanand 2013; Portman 2019b; Portman et al. 2018; USPS 2020b; WWF 2017b), the stamp has neither been a clear success nor a clear failure (Caroline Baumann, USPS CSAC, personal communication).

\section{Funds raised}

The Tiger Stamp's conservation impact cannot be established in ecological terms. Stamp funds have been widely dispersed and mixed with other funding. While even the stamp's smallest contributions to conservation projects- $\$ 299$ for anti-poaching efforts in Kenya (FWS 2019), for instancemay be large enough to advance conservation in a country where GDP per capita is $\$ 1816$ (World Bank 2020), we cannot assess whether such funds advanced policy goals.

In terms of public money, the Tiger Stamp offers a relatively large supplement to Congressional appropriations for MSCFs. FWS received \$11.6 million in MSCF appropriations in FY 2019 and requested \$6 million in FY 2020 (Crafton 2019). Stamp sales 2017-2018 raised about \$2 million (Sheikh et al. 2017; FWS 2020c). If 2020 sales are similar, they will equate to $16.7 \%$ of FWS's requested appropriation. Tiger Stamp funds have been nearly tripled by leveraged funds from ENGOs; these contributed about $\$ 3.8$ million annually from FY2012-2017. The Multinational Species Conservation Funds also receive matching funds; these averaged \$3.68 million/year/fund in FY 2013-17 (Sheikh 2019), so Tiger Stamp matching funds equate to an additional MSCF's worth of matching funds. However, the Neotropical Migratory Bird Conservation Act, a similar program, received \$14.2 million in leveraged funds in FY 2018 alone. Overall, while contributions tied specifically to the stamp might have been lost in its absence, these resources would likely have continued to fund conservation, given ENGOs' missions.

Tiger Stamp funds are tiny compared to other ENGO activity. WWF, for instance, raised $\$ 119.7$ million from individuals in FY 2019 (WWF 2020d), and the International Fund for Animal Welfare, a lesser-known member of the Multinational Species Coalition, raised $\$ 51.8 \mathrm{~m}$ from supporters (International Fund for Animal Welfare 2019). Panthera, an organization that focuses on wild cat conservation, raised $\$ 4.9$ million, though this total includes grants as well as donations (Panthera 2020b).

\section{Sales}

If stamps printed reflect sales expectations, the Tiger Stamp has not been as effective as anticipated, with almost half of stamps unsold. Tiger Stamp sales, averaging 7.5 million per year, have been lower than sales of other US semipostals (Sheikh et al. 2017; USPS 2020a). Over a billion Breast Cancer Research Stamps have been sold (USPS 2020a). The Stop Family Violence stamp averaged 15 million stamps per year, and the Heroes of 2001 averaged 53 million stamps per year.

However, all of this must be viewed in the context of stamp sales overall. First class mail, which we use as a proxy for stamp use, is declining. When the Breast Cancer stamp was created in 1998, Americans sent more than 100 billion pieces of first-class mail. In 2019, Americans sent 54.9 billion pieces of first class mail (USPS Historian 2020). In 2008, USPS printed about 37 billion stamps, on the order of 120 stamps per American citizen (USPS 2009). In 2019, USPS printed 16.5 billion postage stamps, or 50 stamps per person (USPS 2020c). A stamp sold between 2011 and 2018 would be likely to sell substantially fewer copies than a stamp sold a decade earlier. And indeed, between 2002 and 2006, Heroes of 2001 and Stop Family Violence sold far more stamps annually than Alzheimer's (2017-19) or the Tiger Stamp. The Breast Cancer stamp sold 606.8 million copies from 1998 to 2005 and 453.2 million copies between 2005 and 2020 (GAO 2005; USPS 2020a). The Tiger Stamp sold 26 million stamps in its first 2 years, 2011-13; since then, it has sold 26.7 million stamps (Portman 2014; USPS 2020a).

The factors that have led to the decline in first-class mail are likely to continue. There is some hope in the Postal Service that semipostal stamps will motivate people to buy stamps 
(Betts, USPS, personal communication). The USPS now issues semipostals itself, selling several at once (USPS 2020a). However, declining sales of all semipostals indicate that it may be impossible for stamps in the 2020s to match sales from 20 years before, limiting their effectiveness as public policy tools.

\section{Hortatory influence}

Stamps' effects extend beyond the money raised through sales (Mack 2015). The Tiger Stamp's visual elements - bold printing, appealing coloration, and a charismatic tiger cub-would tend to inspire positive responses, even in people who see it without buying it. Assuming that Tiger Stamps were used, they were seen some 50 million times by letter and card recipients, in addition to people seeing them in passing in post offices and other venues. Advertising viewers absorb images with varying degrees of passivity and consciousness, which affect attitudes and behaviors even if people do not remember seeing them (Hill 2018; On Device Research 2018). Tiger Stamps, backed by the authority of the national government and carrying with them, for many recipients, the spark of excitement brought by the increasingly-rare experience of receiving letters or cards by mail, may have boosted their hortatory power beyond their sales (FWS 2018; Sheikh et al. 2017; GAO 2005). As the Postal Service itself notes, the stamp is a "conversation starter" (FWS 2018). Pictures matter, even for people who do not buy stamps themselves, and appealing images like the Amur cub may help mobilize public emotion (Luxon 2019; Smith et al. 2020), inspiring support for international conservation.

\section{Recommendations}

The Tiger Stamp has been less successful than might have been expected in 2000, but it can continue to support international conservation. We recommend the following:

- USPS should sell all existing stamps, issuing the stamp on its own authority if necessary. Despite the Postal Service's past discomfort with this, stamps have always been policy tools. Semipostals serve the same hortatory purposes as other stamps and support public goals.

- USPS and FWS should capitalize on tigers' pre-existing charisma and build partnerships with places and organizations that identify themselves with tigers. Promotion by partnering organizations has been key to semipostals' success (GAO 2005).

- Semipostal stamps having been challenged by public uncertainty about how funds are spent (GAO 2005), FWS, USPS, and ENGO's should promote the stamp's conservation impact in concrete terms, inspiring consumers by showing them what donations accomplish.

Acknowledgments We wish to thank Emily Witsell for her assistance in formatting the paper, and two reviewers for their helpful feedback.

\section{Compliance with ethical standards}

Conflict of interest The authors declare that they have no conflict of interest.

Open Access This article is licensed under a Creative Commons Attribution 4.0 International License, which permits use, sharing, adaptation, distribution and reproduction in any medium or format, as long as you give appropriate credit to the original author(s) and the source, provide a link to the Creative Commons licence, and indicate if changes were made. The images or other third party material in this article are included in the article's Creative Commons licence, unless indicated otherwise in a credit line to the material. If material is not included in the article's Creative Commons licence and your intended use is not permitted by statutory regulation or exceeds the permitted use, you will need to obtain permission directly from the copyright holder. To view a copy of this licence, visit http://creativecommons.org/licenses/by/4.0/.

\section{References}

106th Congress (2000) Semipostal authorization act. United States Congress

111th Congress (2010) Multinational species conservation funds semipostal stamp act of 2010. United States Congress

116th Congress (2019) Appropriations for Fiscal Year 2020. United States Congress

Albert C, Luque G, Courchamp F (2018) The twenty most charismatic species. PLoS One 13:1-12

All SportsCaster (2020) The 7 most popular team names in American sports. Sportscasting: Pure Sports. https://www.sportscasting.com/ the-7-most-popular-team-names-in-american-sports. Accessed 4 Apr 2019

American Philatelic Society (2018) History of stamps. https://classic. stamps.org/Stamp-History. Accessed 20 Sept 2020

Barua M (2011) Mobilizing metaphors: the popular use of keystone, flagship and umbrella species concepts. Biodivers Conserv 20: 1427-1440. https://doi.org/10.1007/s10531-011-0035-y

Baumgartner F, Jones B (2010) Agendas and instability in American politics. Cambridge University Press, Cambridge UK

Brown H (2010) Multinational species conservation funds semipostal stamp act of 2010. United States House of Representatives, Washington, DC

Bruskotter J, Vucetich K, Slagle K, Berardo R, Singh A, Wilson R (2018) Support for the U.S. endangered species act over time and space: controversial species do not weaken public support for protective legislation. Conserv Lett 11:1-7

Campaign (2012) The history of advertising in quite a few objects: 43 Esso tiger tails. https://www.campaignlive.co.uk/article/historyadvertising-quite-few-objects-43-esso-tiger-tails/1151980. Accessed 20 Sept 2020

Clay W (2019) H.R.1446 - multinational species conservation funds semipostal stamp reauthorization act of 2019. United States House of Representatives. https://www.congress.gov/bill/116th-congress/ house-bill/1446. Accessed 15 Sept 2020 
Crafton R (2019) In focus: U.S. fish and wildlife service: FY2020 appropriations. Washington, DC. https://crsreports.congress.gov/product/ pdf/IF/IF $11204 \#: \sim:$ text=For\%20FY2020\%2C\%20the\% 20Administration $\% 20$ requested, $\% 241.578 \% 20$ billion $\% 20$ (Table\% 201).\&text $=$ Sources $\% 3$ A $\% 20$ CRS $\% 2$ C $\% 20$ with $\% 20$ data $\%$ 20 from $\% 20$ conference\%20report\%20(H.,Rept. Accessed 15 Sept 2020

Davis B, Moretti G (2005) Enforcing U.S. marine protected areas: synthesis report. NOAA, Silver Spring MD

Dayanand N (2013) Innovative conservationfunding source gets fauna \& flora international stamp of approval. Fauna and Flora International. https://www.fauna-flora.org/news/innovative-conservationfunding-source-gets-fauna-flora-international-stamp-of-approval. Accessed 20 Sept 2020

Douglas L, Winkel G (2014) The flipside of the flagship. Biodivers Conserv 23:979-997

Ducarme F, Luque G, Courchamp F (2013) What are 'charismatic species' for conservation biologists? BioSci Master Rev 10:1-8

Dunlap R (2019) Partisan polarization on the environment grows under Trump. Gallup Blog. https://news.gallup.com/opinion/gallup/ 248294/partisan-polarization-environment-grows-trump.aspx. Accessed 8 Jan 2020

Hejny J (2018) The Trump administration and environmental policy: Reagan redux? J Environ Stud and Sci 8:197-211

Hill A (2018) Passive ad exposure. Active ad effectiveness: the unconscious brand effect of digital advertising Interactive Advertising Bureau https://www.iabuk.com/opinions/passive-ad-exposureactive-ad-effectiveness-unconscious-brand-effect-digitaladvertising. Accessed 8 Jan 2020

Home R, Keller C, Nagel P, Bauer N, Hunziker M (2009) Selection criteria for flagship species by conservation organizations. Environ Conserv 36:139-148

International Fund for Animal Welfare (2019) Annual Report July 2018June 2019. https://www.ifaw.org/international/campaigns/2019annual-report/. Accessed 1 Dec 2020

International Union for Conservation of Nature and Natural Resources (2020) The IUCN red list of threatened species. https://www. iucnredlist.org/. Accessed 8 Jan 2020

Jarić I, Courchamp F, Correia R et al (2020) The role of species charisma in biological invasions. Front Ecol Environ 18:345-353

Jepson P, Barua M (2015) A theory of flagship species action. Conserv Soc 13:95-104

Kelloggs (2005) Tony the tiger and his all-star friends help kids earn their stripes. http://newsroom.kelloggcompany.com/news-releases? item $=76098$. Accessed 8 Jan 2020

Kenmore Stamp Company (2020) WWF Laos tigers - 1984. https://www. kenmorestamp.com/topicals/lora-fauna/world-wildlife-fund/laostigers. Accessed 8 Jan 2020

Kolbert E (2014) The sixth extinction: an unnatural history. A\&C Black, London

Lorimer J (2007) Nonhuman charisma. Environ Plan D 25:911-932

Lundberg P, Vainio A, MacMillan D, Smith R, Veríssimo D, Arponen A (2019) The effect of knowledge, species aesthetic appeal, familiarity and conservation need on willingness to donate. Anim Conserv 22: $432-443$

Luxon E (2019) Mobilizing environmental sentiment through the media. Environ Politics 28:639-662

Mack A (2015) Postal poetry: The significance of stamps. Ethnogr Prax in Industry Conf Proc. https://doi.org/10.1111/1559-8918.2015. 01059

Miller H, Terrell P (1991) Note on policy: the charity stamp. Soc Serv Rev 65:157-165

Office of Congressional and Legislative Affairs (2019) Pending legislation

On Device Research (2018) Passive ad exposure. Active ad effectiveness: The unconscious brand effect of digital advertising. https://www. iabuk.com/opinions/passive-ad-exposure-active-ad-effectivenessunconscious-brand-effect-digital-advertising. Accessed 20 Sept 2020

Owens S (2000) Review of the breast cancer research stamp program. https:/www.uspsoig.gov/sites/default/files/document-library-files/ 2015/RG-AR-00-002_0_1.pdf. Accessed 20 Sept 2020

Panthera (2020a) Tiger: the state of the tiger. https://www.panthera.org/ cat/tiger. Accessed 8 Feb 2020

Panthera (2020b) Panthera 2019 Annual Report. https://www.panthera. org/Annual-Report-and-Financials. Accessed 5 Dec 2020

Portman R (2014) Portman endangered species stamp bill passes senate. https://www.portman.senate.gov/newsroom/press-releases/ portman-endangered-species-stamp-bill-passes-senate. Accessed 20 Sept 2020

Portman R (2019a) Multinational species conservation funds semipostal stamp reauthorization act of 2019. United States Senate. https:// www.congress.gov/bill/116th-congress/senate-bill/652. Accessed 20 Sept. 2020

Portman R (2019b) Portman, Udall introduce bill to ensure remaining stamps to promote wildlife conservation are sold. https://www. portman.senate.gov/newsroom/press-releases/portman-udallintroduce-bill-ensure-remaining-stamps-promote-wildlife. Accessed 20 Sept 2020

Portman R, Udall T, Carper T (2018) Letter to postmaster general Megan Brennan

Roberge JM, Angelstam P (2004) Usefulness of the umbrella species concept as a conservation tool. Conserv Biol 18:76-85

Schneider A, Ingram H (1990) Behavioral assumptions of policy tools. J Politics 52:510-529

Sheikh P (2019) Multinational species conservation fund: FY2020 appropriations, Washington, DC

Sheikh P, Dorheim K, Christensen M (2017) Multinational species conservation fund semipostal stamp, Washington, DC

Smith R, Veríssimo D, Isaac N, Jones K (2012) Identifying Cinderella species: uncovering mammals with conservation flagship appeal. Conserv Lett 5:205-212

Smith R, Salazar G, Starinchak J, Thomas-Walters L, Veríssimo D (2020) Social marketing and conservation. In: Sutherland W, Brotherton P, Davies Z, Ockendon N, Pettorelli N, Vickery J (eds) Conservation Research, Policy and Practice. Cambridge University Press, Cambridge UK, pp 309-322

Thailand Post Company and World Wildlife Fund (2011) Wild animal postage stamps (7th series) - tigers with WWF logo. Siam Stamp Catalogue http://wwwsiamstampcom/catalogue/indexphp?id=952 Accessed 8 Dec 2020

Thompson B, Rog S (2019) Beyond ecosystem services: using charismatic megafauna as flagship species for mangrove forest conservation. Environ Sci Pol 102:9-17

Tulchin Research (2015) Poll finds overwhelming, broad-based support for the endangered species act among voters nationwide. https:// e arthjustice.org/sites/default/files/files/ PollingMemoNationalESASurvey.pdf. Accessed 21 Sept 2020

US Fish and Wildlife Service (2011) Stamp out extinction. Open Spaces. https://www.fws.gov/news/blog/index.cfm/2011/9/20/Stamp-OutExtinction. Accessed 8 Jan 2020

US Fish and Wildlife Service (2015) Detroit Tigers root, root, root for endangered tigers. Open Spaces. https://www.fws.gov/news/blog/ index.cfm/2015/4/6/Endangered-Tigers-Root-Root-Root-for-theDetroit-Tigers. Accessed 8 Jan 2020

US Fish and Wildlife Service (2018) 3 reasons why you should use save vanishing species stamps. Medium. https://medium.com/@ USFWS/3-reasons-why-you-should-use-save-vanishing-speciesstamps-88f739eb489e. Accessed 21 Sept 2020

US Fish and Wildlife Service (2019) Save vanishing species semipostal stamp funding FY2012-2017. https://www.fws.gov/international/ pdf/tiger-stamp-grants.pdf. Accessed 21 Sept 2020 
US Fish and Wildlife Service (2020a) Tigers. https://www.fws.gov/ international/animals/tigers.html. Accessed 21 Sept 2020

US Fish and Wildlife Service (2020b) Tiger (Panthera tigris). Environmental Conservation Online System. https://ecos.fws.gov/ ecp0/profile/speciesProfile?spcode $=$ A043. Accessed 8 Jan 2020

US Fish and Wildlife Service (2020c) Save vanishing species stamps are back. Open Spaces. https://www.fws.gov/news/blog/index.cfm/ 2020/2/21/Save-Vanishing-Species-Stamps-are-Back. Accessed 8 Jan 2020

US Government Accountability Office (2003) Breast cancer research stamp: effective fund-raiser, but better reporting and cost-recovery criteria needed. https://www.gao.gov/products/GAO-03-1021. Accessed 21 Sept 2020

US Government Accountability Office (2005) "Factors affecting fundraising stamp sales suggest lessons learned." https://www.gao.gov/ products/GAO-05-953. Accessed 21 Sept 2020

US Government Accountability Office (2007) US postal service: agencies distribute fund-raising stamp proceeds and improve reporting. https://www.gao.gov/products/GAO-08-45. Accessed 21 Sept 2020

US Postal Service (2009) Comprehensive statement on postal operations 2008. https://about.usps.com/strategic-planning/cs08/welcome.htm. Accessed 21 Sept 2020

US Postal Service (2017) Special limited-edition national championship commemorative envelopes and artwork available at select SC post offices. https://about.usps.com/news/state-releases/sc/2017/sc 2017 0302.htm. Accessed 21 Sept 2020

US Postal Service (2020a) Community activities: semipostal stamps. https://about.usps.com/what/corporate-social-responsibility/ activities/semipostals.htm. Accessed 21 Sept 2020

US Postal Service (2020b) Save vanishing species: First class semipostal 65ф." Postal Store. https://store.usps.com/store/product/buy-stamps/ save-vanishing-species-S_576674. Accessed Jan 8, 2020

US Postal Service (2020c) Postal facts: Postage stamps. https://facts.usps. com/stamps/. Accessed Jan 8, 2020

US Postal Service Citizens' Stamp Advisory Comittee (2019) Stamp subject selection criteria. https://about.usps.com/who-we-are/csac/ criteria.htm. Accessed 21 Sept 2020

US Postal Service Historian (2019) Rates for domestic letters since 1863. https://about.usps.com/who-we-are/postal-history/domestic-letterrates-1792-1863.pdf. Accessed 21 Sept 2020

US Postal Service Historian (2020) First-class mail volume since 1926. https://about.usps.com/who-we-are/postal-history/first-class-mailsince-1926.htm. Accessed 21 Sept 2020
Verissimo D (2019) The past, present, and future of using social marketing to conserve biodiversity. Soc Mar Q 25:3-8

Verissimo D, MacMillan D, Smith R (2011) Toward a systematic approach for identifying conservation flagships. Conserv Lett 4:1-8

Walpole M, Leader-Williams N (2002) Tourism and flagship species in conservation. Biodivers Conserv 11:543-547

Wildlife Conservation Society (2020a) Amur tiger ecology. https://russia. wcs.org/en-us/Wildlife/Amur-Tigers/Amur-Tiger-Ecology.aspx. Accessed 8 Jan 2020

Wildlife Conservation Society (2020b) Congress, renew the tiger stamp! $\mathrm{https}$ ://secure.wcs.org/campaign/congress-renew-tiger-stamp-2019. Accessed 21 Sept 2020

World Bank (2020) Kenya: Data. https:/data.worldbank.org/country/ kenya. Accessed 21 Sept 2020

World Wildlife Fund (2010) Stamp of approval. https://www. worldwildlife.org/stories/stamp-of-approval. Accessed 8 Jan 2020

World Wildlife Fund (2014) A stamp to protect wildlife. https://www. worldwildlife.org/stories/a-stamp-to-protect-wildlife. Accessed 21 Sept 2020

World Wildlife Fund (2017a) Know your flagship, keystone, priority and indicator species. Global Species Programme. http://wwf.panda.org/ our_work/wildlife/flagship_keystone_indicator_definition/. Accessed 3 Dec 2019

World Wildlife Fund (2017b) On world wildlife day, give your stamp of approval to conservation funding. https://www.worldwildlife.org/ stories/on-world-wildlife-day-give-your-stamp-of-approval-toconservation-funding. Accessed 8 Feb 2020

World Wildlife Fund (2019a) Priority species. https://wwf.panda.org/ knowledge hub/endangered species/. Accessed 5 Apr 2019

World Wildlife Fund (2019b) Tell congress: Help save vanishing species. https://support.worldwildlife.org/site/Advocacy?cmd= display\&page $=$ UserAction\&id=929. Accessed 21 Sept 2020

World Wildlife Fund (2020a) Priority species. https://wwf.panda.org/ knowledge_hub/endangered_species/. Accessed 8 Jan 2020

World Wildlife Fund (2020b) History. https://www.worldwildlife.org/ about/history. Accessed Jan 8, 2020

World Wildlife Fund (2020c) Adopt a tiger. https://gifts.worldwildlife. org/gift-center/gifts/species-adoptions/tiger.aspx. Accessed 8 Jan 2020

World Wildlife Fund (2020d) 2019 WWF-US annual report. https:// wwwworldwildlifeorg/about/financials Acessed 1 Dec 2020

Publisher's Note Springer Nature remains neutral with regard to jurisdictional claims in published maps and institutional affiliations. 